ИВО АНДРИЋ ${ }^{1}$

Књижевник и дипломата Иво (Иван) Андрић рођен је у Доцу код Травника 9. или 10. октобра 1892, а умро у Београду 13. марта 1975. године.

Андрићи су Сарајлије, чувени мајстори млинова за кафу. Отац Антун, подворник, умро је, као и његова браћа, од сушице 1894, у 34. години. Мајка Катарина, р. Пејић, чија је породица такође погођена раним умирањима, носи двогодишњег сирочића Ивана у Вишеград код Антунове сестре Ане и њеног мужа Ивана Матковчика, аустријског чиновника пољског поријекла. Ту дијете завршава основну школу (1903), задржавши у најљепшој успомени учитеља Љубомира Поповића, склоног књижевности и писању.

Са стипендијом из Вишеграда од 200 круна уписује 1903. Велику гимназију у Сарајеву и станује с мајком на Бистрику. Због скромног успјеха у школи (поновио је шести разред) стипендија се стално смањује и на крају бива укинута. Упознаје професора др Тугомира Алауповића и у њему налази трајног и поузданог пријатеља. Интензивно учи стране језике читајући свјетске класике. Ангажује се око покрета „Млада Босна” и у Босанској вили 1911. објављује прву пјесму у прози У

1 Претходно објављено у: Иво Андрић : мост и жртва / Јован Делић ; [превод на енглески Ангелина Чанковић Поповић ; фотографије Владимир Поповић]. - Нови Сад : Православна реч ; Београд : Музеј града Београда, 2011 (Суботица : Ротографика). 
сумрак, а затим Блаgа и добра мјесечина, као и преводе (1912) са словеначког и других језика (В. Јерајева, Ј. Мурн, А. Медвед, О. Жупанчич, Ф. Левстик, В. Витмен, А. Стриндберг) потписујући их с Ив. Ан. Из гимназије излази с лијепим знањем више језика, иако посљедња два разреда завршава само с добрим успјехом и довољним оцјенама. Скромни матурант (1912) већ је пјесник и полиглота. Пред одлазак из Сарајева најмлађи је у генерацији која носи немире и тражи промјене (Гаћиновић, Митриновић, Јевтић, Палавестра, Варагић, Радуловић, Мрас, Видаковић, Самоковлија).

Са стипендијом хрватског друштва „Напредак” 14. Х1912. уписује Мудрословни факултет Краљевског свеучилишта Фрање Јосифа I у Загребу. Упознаје А. Г. Матоша, који на њега оставља трајан траг, и интензивно учествује у студентском друштвеном животу. Током прва два семестра, вјероватно ради стипендије, похађа математичко-природословни одсјек. У Горњем граду упознаје породицу Гојмерац и са млађом ћерком Рудолфа Гојмерца, студенткињом конзерваторија, Евгенијом, одржава интензивну преписку све до њене смрти од леукемије 1915.

Други семестар овјерава 12. VII 1913, а средином октобра уписује трећи семестар славистике у Бечу. Одржава интензивне везе са Загребом и посредством пријатеља сарађује у Савременику, Вихору и Хрватском покрету, нарочито током 1914. У Бечу упознаје дјела Серена Кјеркегора, а вјероватно се среће и са идејама психоанализе. Сарађује са националним клубовима „Зора” и „Звонимир”, гдје говори поводом Матошеве смрти. У Бечу има озбиљне проблеме с климом, побољева од плућа и грла, па моли Т. Алауповића да посредује око дозволе за студирање на неком словенском универзитету. Могућно је да су, осим здравствених, постојали и политички разлози за напуштање Беча. 
Четврти семестар уписује на Филолошком одсјеку Јагелонског универзитета у Кракову 24. IV 1914, гдје проводи узбудљиве, пријатне и драгоцјене мјесеце. Дружи се са сликарима Ј. Бијелићем, Р. Петровићем и П. Тијешићем. Упознаје велику словенску литературу, а Пољска га привлачи и као политички несрећна словенска земља. Пише рефлексивну поезију и јуна 1914. Друштво хрватских књижевника у Загребу објављује му шест пјесама у прози у панорами Хрватска млада лирика.

На вијест о Сарајевском атентату одмах се враћа у земљу, заборавивши чак и лична документа. У Сплит стиже у ноћ 17. јула, гдје се држи повучено, али већ 28. јула бива ухапшен. Из Сплита га спроводе у шибеничку, а онда у мариборску тамницу, гдје остаје до 20. III 1915, понижен и окренут поезији. Интерниран је у Овчарево код Травника, а од средине јула у Зеницу. Овдје је у контакту са мајком и са тамошњим фрањевцима, што ће бити важно за његову литературу. Слиједи регрутација 12. VIII, служење у Војној болници у Зеници, општа амнестија јула 1917, одлазак у Вишеград, па у Загреб, гдје у болници Милосрдних сестара учвршћује пријатељство с Ивом Војновићем. Упознаје списатељицу и полонисткињу Зденку Марковић. Уписује се на Свеучилиште.

С Н. Бартуловићем, Б. Машићем и В. Ћоровићем покреће часопис изразито југословенске оријентације Кюижевни јуд, чији први број излази 1. I 1918. и објављује књигу пјесама у прози Ex Ponto (1918), с предговором Н. Бартуловића. У Загребу дочекује пад Аустроугарске и стварање Краљевине СХС. У загребачким Новостима објављује чланак Незвани нека шуте, у којем позива на разум и оштро реагује на противнике уједињења. Муче га плућа и општа атмосфера у Загребу. Више пута се обраћа новопостављеном министру Т. Алауповићу ради преласка у Београд. Лијечи се и одлази у Сплит (1919), а одатле у Сутиван на Брачу, гдје довршава књигу поетске прозе Немири. Здрав- 
ствено препорођен, преко Вишеграда, враћа се у Загреб.

Октобра 1919. сели се у Београд, гдје бива постављен за секретара треће класе у Министарству вера. Тиме почиње нова фаза у његовом животу и стваралаштву. Овај „млади катол. Србин из Босне, идеални младић” (И. Војновић) све више се везује за српску књижевност и њену традицију. Већ 27. XI у сали „Станковић” хотела „Москва” учествује на књижевној вечери уз Сиба Миличића, Симу Пандуровића, Јосипа Колара, Даницу Марковић, Мирка Королију и Тодора Манојловића. Милош Црњански му посвећује пјесму Етеризам у Лирици Итаке. У дипломатску службу ступа 14. II1920; постављен је за вицеконзула III класе Генералног конзулата у Њујорку, а 16. II је новим рјешењем упућен у посланство при Ватикану, те одлази у Рим. У Београду му излазе приповијетка Пут Алије Ђерзелеза и ћирилично издање Ex Ponta; у Загребу Немири, у Српском книжевном гласнику, чији ће стални сарадник бити, прича Дан у Риму. Била је то преломна година за оба његова животна опредјељења - књижевност и дипломатију. За чиновника Генералног конзулата у Букурешту постављен је 1. Х 1920. СКГ му објављује причу Ћоркан и Швабииа. Наредне године премјештен је у конзулат у Трсту. У часопису Мисао 1922. објављује циклус пјесама Шта сағьам и шта ми се догађа, а исте године штампа и приповијетке $3 а$ логороваға и Жена од слонове кости. За вицеконзула у Грацу постављен је 12.11923 , гдје уписује Филозофски факултет. Објављује приповијетке Љубав у касаби, Мустаба Мацар и У мусафирхани. У јуну одлази у Дубровник и Вишеград на лијечење, а по повратку сазнаје да је, због незавршеног факултета, отпуштен из службе МИД-а, што ће се званично потврдити 31. XII 1923. Јуна 1924. одбранио је докторску тезу Die Entwicklung des geistigen Lebens 
in Bosnien unter der Einwirkung der türkischen Herrschaft (Развој духовног живота у Босни под утицајем турске владавине). У Вишеграду му 12 . VIII умире теча и поочим Иван Матковчик, а 15. IX враћен је у службу и мјесец дана касније разријешен дужности у Грацу.

У главну архиву МИД-а прелази 1 . XI, а потом у политичко одјељење. СКЗ му, у XXVII колу, објављује Приповетке, за које ће 1925. добити награду из фонда Љубе Михаиловића. Те године, преко књиге Михајла Гавриловића Исписи из париских архива, почиње његово интересовање за грађу из које ће се развити Травничка хроника. СКГ му 1925. објављује Мару милоснииу и Мост на Жепи, а Гласник Савеза трезвене младежи прве записе из збирке Знакови поред пута. Мајка му умире 15. XII у Сарајеву. На њеној надгробној плочи пише: „Катарина Андрић, рођена Пејић, 19. VII 1872 - 15. XII 1925. Својој доброј мајци њезин Иван". Крајем 1925. унапријеђен је за секретара 6. групе I категорије у МИД-у. На предлог Б. Поповића и С. Јовановића једногласно је изабран за дописног члана Српске краљевске академије 18. II 1926. За вицеконзула у Марсељу постављен је 24. X 1926. Почетком 1927. умире му тетка (помајка) Ана Матковчик. Упућен је на привремени рад у Париз 9. XII, гдје ће у архиву Министарства спољних послова проучавати кореспонденцију Пјера Давида. Објављује одломак приповијетке Аникина времена (ЛМС) и Легенду о Лаури и Петрарки (СКГ). За вицеконзула у Посланству у Мадриду постављен је 10. IV 1928. Објављује приповијетке Олујаци, Исповијед и Велетовци. Постављен је 4. VI 1929. за секретара посланства у Бриселу. Објављује есеј Гоја с потписом Р. Р. За секретара Сталне делегације Краљевине Југославије при Друштву народа у Женеви постављен је 1.1 1930. Објављује два есеја о Симону Боливару, запис 
Учитељ Љубомир и причу Код казана. СКЗ му 1931. објављује Приповетке као 1. књигу I кола библиотеке "Савременик” и за њу добија награду фонда Коларчеве задужбине. Постаје члан добротвор СКЗ, а 12. Х је постављен за замјеника делегата у сталној делегацији при Друштву народа у Женеви. У календару сарајевске Просвјете објављује путопис Португал, зелена земла. Штампа запис Лежећи над морем и приповијетке Смрт у Синановој текији и На лађи 1932, а у божићном броју Политике за 1933. објављује запис Мостови.

Враћа се у Београд као савјетник у МИД марта 1933. Учествује на конгресу Пен-клубова у Дубровнику 25 - 28. V. У писму др Миховилу Комболу (14. XI) одбија да уђе у Антологију новије хрватске лирике. За члана Књижевног одбора СКГ именован је 16.1 1934, гдје објављује приповијетку Жеђ и први дио прозе Јелена жена које нема. У Идејама објављује фрагмент Разговора с Гојом, а у Политици путопис Шпанска стварност и први кораци у ној. Народно позориште у Сарајеву изводи приповијетку Аникина времена у драматизацији Б. Јевтића (Аникина узбуна), а 23. V унапријеђен је за савјетника 4. групе 2. степена МИД. На Коларчевом универзитету држи предавање Његош као трагични јунак косовске мисли 24. XII 1934, које ће 1935. бити штампано као посебна брошура. Те 1935. објављује приповијетке Бајрон у Синтри, Деца и есеј Разговор с Гојом и постаје начелник политичког одјељења МИД- а. Објављује 1936. у СКЗ Приповетке II. За помоћника министра МИД-а именован је 5. XI 1937. Те године му излази избор приповједака на пољском, објављује приповијетку Труп и есеј Ликови, а у Бечу, сакупљајући грађу за Травничку хронику, проучава извјештаје аустријских конзула из Травника (1808 -1817), Паула фон Митесера и Јакоба фон Паулича.

Прву монографију о њему објављује др Никола Мирковић 1938. На предлог Б. Поповића, J. Предића и 
Ђ. Јовановића 16. II 1939. изабран је за редовног члана Српске краљевске академије. Постављен је за опуномоћеног министра и изванредног посланика Краљевине Југославије у Берлину 1. IV 1939, а 19. IV предаје акредитиве Адолфу Хитлеру. Интервенише код њемачких власти послије хапшења научника и културних радника у окупираној Пољској. На њемачком му излази књига приповједака (Беч-Лајпциг) у преводу Алојза Шмауса, а у Софији такође приповијетке на бугарском. Током 1940. објављује у СКГ (Чаша, Стазе, Вино), а 1941. нуди оставку на амбасадорско мјесто која није прихваћена, па 25. марта присуствује потписивању Тројног пакта у Бечу као званични представник Југославије.

Послије бомбардовања Београда напушта Берлин 7. IV, одбија понуду да се склони у Швајцарску и враћа се у Београд, гдје станује код адвоката Бране Миленковића. Пензионисан је 15. XI 1941. Одбија да прими пензију и да потпише „Апел српском народу», којим се осућује отпор окупатору. Одбија да било шта објављује под окупацијом.

Током рата живи повучено и ради на уобличењу својих романа Травничка хроника, На Дрини ћуприја и Госпођица. Прва два објављује у Београду, а Госпођииу и изабране приповијетке у Сарајеву 1945. Био је вијећник III заседања ЗАВНОБИХ-а и члан двају делегација писаца у посјети Бугарској. На свечаном скупу у САНУ 24. I 1946. чита приступну бесједу О Вуку као писиу. Исте године изабран је за предсједника Савеза књижевника Југославије и потпредсједника Друштва за културну сарадњу са Совјетским Савезом. Путује у Москву, Лењинград и Стаљинград, а као гост учествује у раду Словенског конгреса у Београду 8-14. XI 1946. Живи у Београду и Сарајеву; објављује Злостављьюье и Писмо из 1920. године. Током 1947, поводом стогодишњице Гор- 
ског вијенца и побједе Вуковог језика, учествује у прославама, објављује радове о Вуку и Његошу и пише о Вуку један сценарио. Објављује Причу о везировом слону и Причу о кмету Симану. Члан је Президијума Народне скупштине БиХ. Путује као члан југословенске делегације писаца у СССР (Азербејџан, Баку) на прославу 800-годишњице пјесника Низамија. У Будимпешти му излази превод романа На Дрини ћуnрија, у Прагу Госпођица. Учествује на свјетском конгресу интелектуалаца у Вроцлаву (25 - 28. VIII 1948). Појављује му се превод На Дрини ћуприје у Софији и Травничке хронике у Љубљани, а у Београду објављује Нове приповетке. Учествује на свјетском конгресу присталица мира у Паризу 19-27. IV 1949. и бива поново изабран за председника Савеза књижевника Југославије. Присуствује савјетовању младих писаца Југославије у Београду. Добија награду за књижевност Владе ФНРЈ за Нове приповетке.

Априла 1950. изабран је за посланика Већа народа Народне скупштине ФНРЈ. Објављује приповијетку Бифе Титаник. За дописног члана ЈАЗУ изабран је 29. VI 1951. Поводом стогодишњице Његошеве смрти објављује рад Љуба Ненадовић о Његому у Италији и говори о Његошу на Цетињу (5. IX) и у Београду (31. Х). У Загребу присуствује скупу за мир и међународну сарадњу (23-27. Х). Поводом годишњице смрти Петра Кочића говори о земљи, људима и језику у његовој прози. Излазе му Нове приповетке на македонском у преводу Б. Конеског и на словеначком Прича о везировом слону и друге приповетке. Објављује приповијетку Знакови. Учествује у раду III конгреса Савеза књижевника Југославије (5 - 7. Х). Те године настаје Андрићев портрет Б. Јакца и биста С. Стојановића. Објављује приповијетке На сунчаној страни, На обали, Под грабићем. Од 15. до 27. V 1953. борави у Турској у саставу парламентарне делегације (Анкара, Измир, Бруса, Истам- 
бул). Први пут послије Другог свјетског рата посјећује Вишеград. Изабран је за дописног члана Словенске академије знаности и умјетности 2. VI 1953. У Цириху му излази На Дрини ћуприја - први превод Андрићевог романа на Западу. Објављује приповијетке Немирна година, Аска и вук и Лица.

У Матици српској му 1954. излази Проклета авлија, у СКЗ Одабране приповетке, а исте године објављује и путопис о Почитељу. У Новом Саду, гдје се одмара у Јодној бањи, држи циклус предавања о Петру Кочићу на тек основаном Филозофском факултету. У Приштини му излазе Одабране приповетке на албанском. У режији В. Погачића снимљен је филм Аникина времена. Први је потписник Новосадског договора о српскохрватском језику. Постаје члан КПЈ 13. ХІІ 1954. Од 15. до 17. Х 1955. учествује у раду Савеза књижевника Југославије у Охриду. Објављује у сарајевском Животу рад о Исаку Самоковлији.

Поводом 75-годишњице Прве мушке гимназије у Сарајеву (раније Велике гимназије) држи краћи говор. Савез књижевника Југославије додјељује му награду за Проклету авлију. Поводом објављивања Травничке хронике, 23. IV 1956. француско-југословенско удружење приређује пријем у његову част у Паризу. У Институту за словенске студије Универзитета у Паризу држи предавање о историјској грађи Травничке хронике, а потом борави у Кини мјесец дана. На првом југословенском сајму књига у Загребу 6. XI одржана је свечана академија посвећена Андрићу и предата му је повеља Савеза књижевника Југославије за животно дјело. У Паризу, Москви и Варшави излазе преводи На Дрини ћуприје, у Софији Проклете авлије, у Будимпешти Травничке хронике. У Бањој Луци присуствује обиљежавању четрдесетогодишњице смрти Петра Кочића (12. XI). Поклања 200000 динара гимназији у Вишеграду за књиге. Постаје 
члан Књижевног савета Просвете и први председник позоришног савјета Југословенског драмског позоришта. Објављује приповијетку Игра. Учествује у раду пленума Савеза књижевника Југославије 18. XII у Загребу.

Петар Џаџић објављује студију Иво Андрић. Расте научни интерес за његово дјело. Мидхат Шамић је на Сорбони 1958. одбранио докторску дисертацију Историјски извори „Травничке хронике» Иве Андрића. Жени ce 27. IX 1958. Милицом Бабић, костимографом Народног позоришта, ћерком трговца Стевана и Зорке Бабић, рођеном у Шапцу 2. IX 1909, удовицом Ненада Јовановића. Свједоци су Александар и Јулијана Вучо. Сели се из Призренске 9 у свој први посљератни стан у Улици Пролетерских бригада 2а. Објављује приповијетке Панорама и У завади са светом, и једини предговор, који је написао за књигу 3. Џумхура Некролог једној чариији. У Лондону излази Травничка хроника, у Лајпцигу Госпођица, у Вршцу књига приповједака на румунском. Поводом објављивања књиге На Дрини ћуприја путује у Лондон 23. II и среће се с М. Црњанским, тада још увијек емигрантом. Послије смрти А. Белића 1960. одбија приједлог да буде председник САНУ. Говори на комеморацији о вајару Сретену Стојановићу 4. XI 1960. Објављује збирку приповједака Лииа у Загребу. У част конгреса Савеза књижевника Југославије учествује 15. IX 1961. на књижевној вечери у Сарајеву, а 19. Х говори на скупу Одељења књижевности и језика САНУ о хиспанологу Калмију Баруху, пријатељу из Сарајева и Мадрида.

Нобелова награда за књижевност додијељена му је 26. X 1961, а уручена у Стокхолму 10. XII, којом приликом говори Андерс Естерлинг, стални секретар Шведске академије наука, а Андрић држи бесједу о причи и причању. На традиционалној приредби Дан Лущије, 13. XII, у Градској кући у Стокхолму, Андрић крунише најљепшу дјевојку - краљицу свјетлости, Гуди Вадстет, 
a 16. XII отвара изложбу посвећену Р. Тагори. У Матици српској му излази есеј Записи о Гоји с предговором О. Бихаљија Мерина. Одмара се у Швајцарској. Враћа се 3. I 1962. у Београд, гдје се њему у част одржава Свечани скуп у организацији Савета академија ФНРЈ; говоре С. Станковић, Ф. Когој, Ј. Видмар и В. Глигорић. У Паризу у Друштву Француска-Југославија 20. I слависта Андре Вајан држи предавање о Андрићу. У Минхену је, под руководством А. Шмауса, Регине Минде одбранила докторску тезу о Андрићу.

Поводом Андрићевог доласка у Грчку атинска Академија наука 5. III одржава свечану сједницу. Андрић стиже у Атину 7. III са М. Панићем Сурепом, а 9. III одлази у Египат и обилази Каиро, Порт Саид, Александрију и Луксор. На путу се разболио, па се 27. III враћа у Београд, гдје је оперисан на Хируршкој клиници ВМА. Априла 1962. Травничка хроника бива проглашена за најчитанију књигу у Аустрији. Писмом од 17. V обавјештава Савјет за културу БиХ да је половину Нобелове награде поклонио библиотекама ове републике. Крајем маја 1962. у Минхену се објављује докторска теза Регине Минде - осма свеска у едицији Славистички притози: Иво Андрић - студија о юеговој умјетности. Поводом Андрићеве 70-годишњице у Москви се 5. Х одржава свечана академија. На рођендан, 10. X, прима га предсједник ФНРЈ Јосип Броз Тито и предаје му Орден републике са златним вијенцем. Проглашен је за почасног доктора наука Универзитета у Сарајеву. У галерији Р. У. „Буро Салај» у Београду 26. Х отворена је изложба фотографија Иво Андрић у Стокхолму 1961, а 11. XI у Матици српској Кюижевно дело Иве Андрића. САНУ објављује споменицу поводом 70-годишњице. У Југословенском драмском се, уз његово присуство, приказује Проклета авлија у драматизацији J. Ћирилова и режији М. Милошевића. У 
Сарајеву излази студија Мидхата Шамића Историјски основи „Травничке хронике», а на Филозофском факултету у Загребу Бранко Милановић је одбранио докторску дисертацију Андрићева есејистика и юегово кюижевно дјело. Институт за књижевност и уметност у Београду објављује зборник Иво Андрић као своју I књигу посебних издања. Вуков и Доситејев музеј издаје књигу Иво Андрић о Вуку Каращићу (Ђ. Гавела), а Нолит приповијетке Жена на камену, гдје се први пут у цјелости објављује Јелена жена које нема (приредио М. Первић).

Андрићева дјела доживљавају огроман успех у свијету: Травничка хроника излази у Берлину, Паризу, Минхену, Будимпешти, Ослу, Стокхолму, Утрехту, Буенос Ајресу и Хелсинкију, - Госпођица у Москви, Минхену, Лисабону, Милану, Варшави, Будимпешти, Барселони; На Дрини ћуприја у Истамбулу, Букурешту, Атини, Техерану и Лисабону, а приповијетке у Њујорку, Берлину, Бордоу, Стокхолму, Франкфурту, Букурешту, Атини, Техерану и Лисабону. Сабрана дела у 10 књига („Просвета», Београд, „Младост», Загреб, „Свјетлост», Сарајево, „Државна заложба», Љубљана) појављују се 1963; Госпођица излази у Будимпешти, Копенхагену, Братислави, а Травничка хроника у Лондону, Истамбулу, Софији и Франкфурту, приповијетке у Будимпешти, Барселони, Лајпцигу, Братислави и Хамбургу. Милош И. Бандић одбранио је докторску тезу Иво Андрић - загонетка ведрине. У Споменици посвећеној 150-годишьици рођења Петра II Петровића Његоша САНУ налази се Андрићев прилог Над Његомевом преписком. Током јула борави у Стокхолму, гдје се сусреће с писцем Харијем Мартинсоном. Марта 1964. борави у Италији и среће се са С. Квазимодом и А. Моравијом. Од 9. до 13. IV борави у Пољској, гдје постаје почасни доктор Јагелонског универзитета поводом 600 година његовог постојања. У Београду је Живојин Станојчић 
одбранио докторску тезу Језик и стил Иве Андрића, а у Сарајеву Радован Вучковић Наша критика и Андрићево къижевно дело. Годме 1965. и други дио Нобелове награде поклања Босни и Херцеговини за унапређење библиотека, а 150000 динара уплаћује Црвеном крсту Србије за помоћ поплављенима у Војводини. Јула 1965. учествује на конгресу Пен-клубова на Бледу, а од 15. до 17. X у раду симпозијума о посљератном југословенском роману у организацији Удружења књижевника Србије. Госпођица излази у Лондону, На Дрини ћуприја у Берлину, Букурешту и Милану, а приповијетке у Истамбулу, Брижу, Штутгарту, Лајпцигу и Њујорку. Године 1966. На Дрини ћуприја излази у Минхену и Токију, Травничка хроника у Братислави, Госпођица у Лондону и Барселони, а приповијетке у Стокхолму, Варшави, Букурешту и Копенхагену. У Сарајеву 4. X присуствује отварању прве изложбе у Музеју књижевности Босне и Херцеговине о животу и дјелу Петра Кочића. Одбор Кочићевог збора додјељује му 13. VIII 1967. награду „Давид Штрбац», а исте године добија и награду АВНОJ-а. У Москви му излазе приповијетке.

У Херцег Новом му изненада, од срчаног удара, умире супруга Милица Бабић-Андрић 24. III 1968. године. Говори у Нишу поводом отварања универзитета, посјећује Нови Сад и Челарево. Приповијетке му излазе у Милану, Берлину и Њујорку. На ванредној скупштини Матице српске 11. IV 1969. изабран је за сталног члана- сарадника. Борави у Стокхолму (9-30. V) због лијечења очију. У Врању 21. Х присуствује Бориној недељи, гдје је заштитио тада политички нападнутог Драгослава Михаиловића. ТВ Загреб приказује филм рађен по приповијеци Жеђ у адаптацији К. Новосела и режији J. Марушића. На Дрини ћуприја излази у Бриселу, Госпођица у Берлину, приповијетке у Холандији, Рио де Жанеиру, Будимпешти. Поново одлази у Сток- 
холм ради лијечења очију (10 - 17. I 1970). У Сарајеву посјећује изложбу о животу и дјелу Исака Самоковлије. Диплома почасног члана Академије наука и умјетности БиХ додијељена му је 2. VI 1970, a 19. VI признање Просвјетног сабора Хрватске да је добио највише гласова у анкети међу средњошколцима „Мој најдражи писац». Добија 27-јулску награду БиХ за животно дјело, чији новчани износ поклања овој републици за унапређење библиотека. Отвара XV међународни сајам књига у Београду 22. Х у име предсједника републике. У Театру поезије на Р. У. „Ђуро Салај» у Београду изведени су Крилаши мостови у адаптацији и режији М. Мисаиловића. На Дрини ћуприја излази у Барселони, а приповијетке у Братислави и Милану. Скупштина Културно-просветне заједнице Србије додјељује му специјалну Вукову награду (која му је уручена 25. IV1972). За почасног грађанина Вишеграда проглашен је 10. Х1971. Поводом 400-годишњице ћуприје на Дрини објављено je четворојезично библиофилско издање Mocma на Жепи (српски, енглески, њемачки, италијански).

СКЗ га је, поводом своје 80-годишњице, изабрала за доживотног почасног предсједника 22. V 1972. Југословенско драмско отвара сезону 24. IX премијером сценске адаптације Лииа у режији Олге Савић. За почасног доктора Универзитета у Београду проглашен је 3. Х1972. Поводом 80-годишњице живота Политика му 6. Х, приликом предаје награда ученицима основних школа на конкурсу Политике за деиу, свечаности којој је редовно присуствовао, уручује умјетничку слику Војислава Станића, Златна спомен-плакета Београда уручена му је 8. X, a 10. $\mathrm{X}$ потпредсједник републике Рато Дугоњић уручује му Орден јунака социјалистичког рада. Присуствује свечаној академији у Скупштини БиХ коју, њему у част, приређује АНУБиХ; говорио је академик Мидхат Бегић. Посјећује 
Травник, гдје присуствује прослави југословенске акције „Мјесец дана књиге» и открива плочу на згради прве травничке библиотеке, основане 1706, а затим одлази даље у Вишеград. Народна библиотека у Београду уручује му почасну чланску карту број један 5. XII1972, а он узвраћа библиофилским издањем Проклете авлије што су га објавили удружени издавачи у 200 примјерака с четири оригиналне графике Б. Кршића. Доста путује по земљи и 1973. у Мостару му је уручена златна плакета града. Поклања Музеју књижевности у Сарајеву више својих књига и налив-перо којим је писао од јесени 1936. до почетка 1945.

Од почетка 1974. не осјећа се добро. О здрављу му брину неурохирург проф. др Слободан Костић и проф. др Исидор Папо, али све до децембра учествује у књижевном животу и ради на рукописима Куће на осами и Знакова поред пута. У децембру је сасвим лошег здравља, па 5. XII усмено саопштава Гвоздену Јованићу и Милану Ђоковићу своју тестаментарну жељу, коју ће озваничити Први општински суд у Београду 20. VI1975. Дугогодишња Андрићева сарадница Вера Стојић одрекла се свог дијела насљедства у корист Андрићеве задужбине. Оригинални рукописи и преписка биће предата на чување САНУ, а рукопис романа На Дрини ћуприја уступљен је Музеју књижевности у Сарајеву. На кардиолошко одјељење Б клинике превезен је 17. XII у подне, a 18. XII пренијет је на Клинику за унутрашње болести BMA, гдје остаје све до смрти 13. III 1975. На комеморативној сједници у САНУ говоре Скендер Куленовић и Јосип Видмар 14. III, а приликом сахране од Андрића се опраштају Павле Савић, председник САНУ, Родољуб Чолаковић, члан Савјета федерације, и Киро Глигоров, предсједник Скупштине СФРЈ. Глумац Љуба Тадић прочитао је Андрићев текст Стазе. На Новом гробљу, у Алеји великана, положена је Андрићева урна 24. IV 1975. 


\section{Књижевни рад}

Иво Андрић је почео да објављује у Босанској вили 1911. пјесме у прози и слободном стиху, да би се пред сам Први свјетски рат (јуна 1914) појавило шест његових пјесама у зборнику Хрватска млада лирика (Лағска пјесма, Строфе у ноћи, Тама, Потонуло, Јадни немир и Ноћ ирвених звијезда). У збирци Ex Ponto (Загреб, 1918) потврдиће дубоку меланхолију наговијештену пјесмом У сумрак („Али срце је моје тамно језеро, кога ништа не диже и у ком се нико не огледа") и утврђену тамновањем, али ће показати не мање дубоку мисаоност кроз „разговор с душом" (Н. Бартуловић), пониженом, напаћеном и узнемиреном. Ослоњен на лирски сиже и исповиједни монолог, он води пјесму ка поенти и емотивно-мисаоној сентенци, разбијајући ритам и строгу форму пјесника модерне и градећи пјесничку збирку као чврсту цјелину састављену од три циклуса с „епилогом”, што ће бити још наглашеније у такође тродијелној збирци Немири (Београд, 1920), састављеној од циклуса Немир од вијека, Немир дана и Брегови, од којих посљедњи својим насловом обзнањује његов трајни симбол. Творац ове поезије је у неспоразуму, чак и у расколу са свијетом, заинтересован за домете лиричара разних епоха и народа и њихово превођење, захваћен немирима и преокупацијама пјесника авангарде, близак експресионистима. Ex Ponto се може разумјети као „мисаони дневник младог заточника”, а Немири као „списатељска бележница човека који тражи своје место у свету: та збирка истрзаних мисаоних исповести, сећања, алегорија и парабола сва је саздана од скица, опита, духовног трагања. Поред класног бунта и Кјеркегоровог хришћанства овде као да се осећа известан рефлекс Бергсоновог интуиционизма, ту се бурно укрштају духовна струјања једног усталасаног доба" (И. Тартаља). 
Андрић за живота више неће објављивати ни прештампавати своје пјесничке збирке. Дистанцира се од исповиједног тона и првог лица, преусмјеривши се на приповиједање и треће лице. Пјесме ће писати ријетко, али ће то чинити све до 1973. када је написана пјесма Ни богова, ни молитава, са слутњом краја и чежњом за ширином, пространством, отвореним видиком и слободним дахом. Постхумно ће бити састављена и објављена збирка Шта сағам и шта ми се догађа (Просвета, Београд, 1976), а у Сабраним делима Андрићеве лирске пјесме обједињене су у једанаестој књизи.

Исповиједни тон ће, међутим, бити задржан у записима Знакови поред пута, које је почео да објављује 1925. године и писао до краја живота. То је лирско-медитативна проза, састављена од кратких, цјеловитих, самосталних, веома „збијених” текстова с поентом, које је писац сабрао у засебну цјеловиту књигу, постхумно објављену (1976). Из ње зрачи огромно животно, умјетничко и интелектуално искуство. Ови записи су, по форми и по дубини, јединствени у нашој књижевности племенити и срећно нађени жанровски хибрид који је у себи објединио елементе лирске пјесме, есеја, дневника и особеног путописа.

У својој докторској дисертацији, која је објављена на српском 1982. у преводу 3. Константиновића у првом броју Свезака Задужбине Иве Андрића, наговијестио је теме које ће обрађивати у приповијеткама и романима. Писац изразито негативно вреднује утицај турске владавине и богумилства, видећи у њима кривце за подизање оног „зида” који је у Босни успостављен према Европи.

Медитација и рефлексија, укрштање критичког мишљења, лирске дирнутости и поетске визије карактеристични су за цјелокупно Андрићево стваралаштво, што указује на непрекинуту есејистичку нит која се кроз то дјело провлачи. Као есејиста Андрић, уживља- 
вајући се до идентификације, скицира портрете низа пјесника и приповједача, знаменитих историјских личности и умјетника. Есеј је изворни начин Андрићевог писања; „бескрајна медитација која тече из немира” (И. Тартаља); најчешће претходи неком наративном дјелу и по правилу га проткива. А откривајући друге открива и себе; он даје продорне погледе на своје немирно доба, рат и фашизам, при чему је „одлучно стао на ивицу смисла и свесно повео свој неми разговор с апсурдом" (К. Остојић). Већ у раним критичким написима даје драгоцјене осврте на писце и књиге. Током година постепено и све више уводи нас у тајне своје поетике исказујући личне погледе на језик, књижевност и традицију и везујући се најнепосредније за народну поезију и мит, Његоша и очајничку девизу из Горског вијенца: „Нека буде што бити не може”, а посебно уз Вука као писца и „учитеља енергије”. Живо интересовање и наклоност у својој есејистици показао је за многобројне класике и модерне писце с разних страна свијета. У Сабраним делима његови есеји су сакупљени и распоређени у двије књиге: Историја и тегенда и Уметник и юегово дело. Привучен жељом за даљинама („Даљино, мајко свих жеља”) писао је путописе укрштене с есејистичком рефлексијом и нарацијом, некад као путописна писма богата културним асоцијацијама, некад као путописну приповијетку или као сјећање на раније посјећени град (На вест да је Бруса погорела, 1958). Његову путописну прозу објединила је Жанета Ђукић Перишић у књизи Предели и стазе (2002).

Иво Андрић је написао највише приповједака и најбоље приповијетке у српској прози. За живота је објавио пет књига приповједака: Приповетке (1924, 1931, 1936), Нове приповетке (1948), Лица (1960), постхумно Кућа на осами (1976), раније припремљен приповједачки вијенац са оквиром, односно са уводом и једа- 
наест приповједака-портрета. Као засебна публикација објављен је Пут Алије Ђерзелеза (1920), а три избора доносе и нове приповијетке: у Изабраним приповеткама (1951), Панорами (1958) и Жени на камену (1962). Оне су у Сабраним делима распоређене у седам књига: Немирна година, Жеђ, Јелена жена које нема, Знакови, Деия, Стазе, тица, предели, Кућа на осами, груписане према тематској сродности. Стилски бриљантне, тематско-мотивски разнородне, с упечатљивим и разноврсним књижевним јунацима од луда и божјака до везира и силника из епске поезије, од визија и привиђења као оличења жудње за идеалном женом и љубављу до милосница и распусних владатељки људским страстима, од басноликих фигура Аске и вука, кога је надиграла, до фра-Петра који се нагледао свијета и овладао многим занатима и знањима, од Бонвал-паше до Зује - с мајсторски вођеним сижејним линијама и уживљавањима у сасвим разнородне ликове, каткад с елементима лирског и есејистичког, ове приповијетке увијек потврђују мајстора приповиједања и дочаравања најразличитијих предјела, доживљаја, страсти, опсесија, мрачних порока и ријетких врлина. Каткад блиске путопису, с описима праћеним медитацијама (Стазе, лица, предели), каткад портрету (Мустаба Мачар, Прича о кмету Симану, Ђорђе Ђорђевић, Аутобиографија, Мара милосница, цијела Кућа на осами), каткад параболи о умјетности и умјетнику (Мост на Жепи, Панорама) и басни (Аска и вук) или есеју (Тренутак $у$ Топли), каткад пародији епске пјесме с преокретом силника у сметеног јадника и слабића пред женама, с елементима романа (Пут Алије Берзелеза), приповијетке показују велику морфолошку разноврсност и склоност ка укрштању жанрова. Андрићеве приповијетке имају тенденцију уланчавања и циклизације, чиме најављују пишчеву склоност ка доцнијој широкој епској форми. 
Тако „приче о фратрима” слуте Проклету авлију, а истраживачи и приређивачи су указивали на унутарњу повезаност више низова приповједака и објављивали их као цјеловите књиге: Радивоје Константиновић Jeврејске приче (1991), а Жанета Ђукић Перишић је у приповијеткама о Томи Галусу видјела недовршен роман и покушала га реконструисати под насловом На сунчаној страни (1994). Приповијетка Панорама има функцију оквирне и кључне приче у истоименој збирци и показује успомене из дјетињства како лебде и преображавају се у сјећању. У збирци Лица насловна приповијетка такође има функцију оквира, а ликови спонтано навиру у сјећање. У Кући на осами писац је у средишту збивања, како оквирне приповијетке тако и вијенца у цјелини, и њему долазе ликови познатих и непознатих особа.

Све до краја Другог свјетског рата важио је као писац приповједака и новела, да би се 1945. појавила три његова романа и из темеља промијенила слику о писцу и његовом односу према највећем прозном жанру. Прво је априла 1942. завршена Травничка хроника, започета још 1924, у вријеме довршавања докторске тезе. Обузет темом односа Истока и Запада на завичајном тлу, судбином међусобног сучељавања и сукоба Турака, наших људи и Европљана, читајући исписе Михајла Гавриловића из француских архива, срећно је наишао на извјештај Пјера Давида, француског конзула, који је у Травнику провео седам година (18071814). Потом је изводе из Давидовог дневника и његову биографију пронашао у француској ревији за дипломатску историју из 1924, па је документарну грађу допунио радећи у париском Архиву Министарства спољних послова (1927) и бечком Државном архиву (1937), гдје је пронашао извјештаје аустријских дипломата из истог времена. Грађи је додао и књижевна дјела Давида (Александрида) и Де Фосеа (Пут у Босну у годинама 
1807-1808), па се у ратно вријеме, оставши без посла и повучен из јавног живота, предао писању романа. Успоставио је смирен тон љетописца и хроничара немирних времена, уоквирио роман „прстеном” причом о старцима који на почетку сједе последњег петка у мјесецу октобру 1806, а на крају посљедњег петка мјесеца маја 1811. и мирно, пушећи, разговарају у Лутвиној кафани, као да седам немирних година конзулских времена није ни било и претежно хронолошки пустио пред читаоца ликове и догађаје, пратећи их некад с велике дистанце, а каткад из непосредне близине, па и из перспективе самих јунака. Цијела галерија незаборавних ликова промиче пред читаоцима: аустријске и француске дипломате, турски везири, варошки и српски свијет, и најнеобичнији међу њима, травнички љекар Марио Колоња, у коме је могућно видјети елементе пишчевог аутопортрета и оличење приповједачеве способности уживљавања у различите људске заносе и прилике (И. Тартаља). За вишеградску ћуприју Андрић је доживљајно везан од дјетињства. Мотив моста у његовој прози могућно је пратити од новела Љубав у касаби (1923) и Мост на Жепи (1925), преко Знакова поред пута (1930) и лирског есеја Мостови (1933) до романа На Дрини ћуприја, написаног у Београду од јула 1942. до децембра 1943. и састављеног као Хомеров спјев, од 24 поглавља. Приповијетка Рзавски брегови (1924) садржи дио хронике Вишеграда у доба аустроугарске владавине. Писцу су као грађа послужиле многе народне пјесме, легенде и предања, као и историјска грађа из турских, аустријских и венецијанских архива. Андрић је, најпре, на педесетак страна рукописа сачинио прву верзију „Вишеградске хронике” која му је послужила као полазиште за рад на роману. Поглавља романа су компонована као међусобно уланчани новелистички блокови у чијим се језгрима обично 
налази нека трагична судбина. Вишеград и његов мост претворени су у позорницу на којој се одвијају велики догађаји и преламају појединачни животи од почетка градње моста до његовог рушења. На том мосту, који се прво указао иза склопљених очних капака дјечаку који ће постати велики везир Мехмедпаша Соколовић, и којим је велики везир покушавао да премости своју унутарњу црну пругу и ријеку што му је одвајала мајку и завичај, судараће се појединци и војске, цивилизације и вјере, идеје и љубавне несреће, човјек и ђаво. Епски је испричан и укомпонован „сплет малих повести о великим трагедијама" (И. Тартаља).

У вријеме довршавања романа На Дрини ћуприја, скицирао је портрет штедљиве старице из којега ће развити роман Госпођица. Овај роман портрет има у средишту лик жене-тврдице, свеле госпођице Рајке Радаковић, која сједи и дрхти у сумраку у хладној соби у Београду крпећи чарапу, а приповједач прати њене успомене. Ћерка јединица пропалог сарајевског трговца прихватила је очеву опомену о штедњи као тестаментарну жељу и претворила је у порок тешког и неизљечивог тврдичлука, који ће је одвести међу зеленаше и профитере, па ће морати да бјежи с очију својих суграђана чак у Београд, гдје ће је тај исти порок одвести у страх од другога и у потпуну изолацију. Од тврдичлуком изазваног страха она ће и умријети: штедећи на свјетлу, помислила је да је њен покисли капут туђинац опаких намјера и добила смртни срчани удар. Полемишући с богатом европском и домаћом литературом о тврдици, Андрић је израдио портрет жене тврдице с елементима карикатуре и гротеске. Госпођица није могла разумјети своје вријеме, нарочито прве деценије XX вијека, које су историјска позадина романа, нити младе људе које је то вријеме донијело, попут пјесника Петра Будимировића, у којем је Андрић дао сопствени аутопортрет. Овај роман је писцу био нарочито драг, мада одудара од свега осталог што је написао. 
Проклета авлија (1954), вјероватно најбоље Андрићево дјело и квинтесенција његове поетике, започета је 1928. као роман о Џему, млађем сину султана Мехмеда Освајача, пораженом од брата Бајазита у сукобу око престола, доцније играчком у рукама моћника хришћанског Запада. Када је повијест о Џему била при крају, дошло је до потпуне измјене концепције романа, па се роман портрет с елементима хронике преобразио у сложену грађевину у којој ће средишње мјесто добити Џемов биограф Ћамил, младић из Смирне, сасвим обузет Џемом и до идентификације унесен у његову судбину. Он за Џема почиње да употребљава личну замјеницу JА, што ће га не само одвести у тамницу, већ и у нестанак. Тако прича о Џему постаје прича о приповиједању и тамновању. Савршено компонована, с прстеном који је уоквирује - уобручује прича о смрти и сахрани фра-Петра - преломљена кроз низ приповједача (младић - фра Петар - Ћамил - Хаим - Заим), Проклета авлија је једна од најсложенијих, најдубљих и најгушће тканих књига не само на српском језику.

Постхумно објављен, недовршени роман Омерnаша Латас (1976), започет под радним насловом „Сарајевска хроника”, ослоњен је до извесне мјере на историјску грађу из бечког Државног архива и на извјештаје аустријског генералног конзула Димитрија Атанацковића. Извор грађе му је била и књига докумената коју је Фердо Шишић сачинио и публиковао (1938) од исписа из бечког Државног архива. Међутим, током рада Андрић је пажњу с конзула Атанацковића пренио на Омер-пашу Латаса. И овом роману је претходила једна скица. Тицала се Омер-пашиног карактера. Већ ту је истакнута пашина склоност издаји, а онда је на роману стрпљиво рађено деценијама. Има мишљења да роман није завршен због промјене пишчеве концепције: иако су претходни Андрићеви романи били 
строго компоновани и јасно завршени, писац је имао разумијевања и за „отворено дјело”, односно за недореченост и хотимичну недовршеност.

Иво Андрић сједињује медитацију и лирику са митом, „легендом” и историјом, градећи густо приповиједно ткиво, некад симболички а некад вођено према алегорији и параболи. Уочени су доминантни Андрићеви симболи: брегови (збацују са себе све „као мрску кабаницу", опиру се промјенама и налетима вјетра), вјетар (варљивост, несталност, снага и осипање, пожар и миловање), камен (чврстина, стаменост), клесани камен (снага духа; сродни су му тесано дрво и обрађена земла), степенице (успињање), сунце и свјетлост, море (ширина, снага, стихија, изазов и бескрајно огледало); Босна (чвориште сукоба и сусрета Истока и Запада, средиште додира и судара култура и цивилизација), конзули, тумачи, преводиоци и други посредници; странаи, симболи доњега свијета - пацови, мишеви и змије; жртва (било да је ријеч о појединцу и народу); мостови (спајају обале, људе и свјетове); то је жена које нема (привиђење које доноси наду и утјеху, али и буди дубоку меланхолију). Симбол, мит и алегорија утемељени су у животним и историјским чињеницама. Андрић је опсједнут тищима и човјеком; мајстор је портретисања; развио је изузетну способност уживљавања у функцији дочаравања и буђења унутрашњег гласа ствари и људи. Отуда је говор уживљавања најзначајнија стилска особина његовог приповиједања.

Андрић је у креативном дијалогу са свјетском и домаћом традицијом, од старих књижевности Далеког истока, Библије и антике до данашњих дана; од народне пјесме, приче и пословице до својих савременика. Његова поетика је „поетика писца ван свих праваца” (И. Тартаља). Истраживачи упозоравају да је врло пажљиво читао стоике, Марка Аурелија и Епик- 
тета; према Хомеру је одредио број поглавља На Дрини ћynрије; повремено је близак источњачким мудрацима, пјесницима и суфистима; често је и радо читао француске „моралисте”, Паскала, Монтења, Жубера, Игоа, Стендала, Балзака, Бодлера и Флобера, са којим га често доводе у везу; Леон Блоа га је веома занимао; у његовој близини били су Петрарка, Фрања Асишки, Гвичардини, Леопарди, Д’Анунцио, Пирандело, Сервантес и његов тумач, филозоф и антифашиста Унамуно, а нарочито Гоја, чијим гласом је изрекао своја најдубља поетичко-естетичка увјерења о густом ткању и о мартирију без надземаљске утјехе; Пушкин, Љермонтов, Гогољ, Толстој, Достојевски и Горки; из Гетеових дјела је извукао највише исписа; Хајне; Томас Ман му је по схватању мита вјероватно најближи од свих романсијера; Витмен, Стриндберг, Хамсун и Вајлд; романтичари Бајрон, Китс, Словацки, Мицкјевич. Ф. Достојевског и Т. Мана сматрао је најзначајнијим писцима на размеђу вијекова, а Кјеркегор је оставио у његовој души трајан траг. О тајни и ћутању је правио исписе из Библије, Плутарха, Гетеа, Китса, Бодлера, Ничеа, Вилије де Лил-Адама, Леона Додеа. У домаћој књижевности упоришта су му Његош, Вук, народна поезија, али и Б. Радичевић, Змај, П. Прерадовић, Љ. П. Ненадовић, С. Матавуљ, кога је сматрао мајстором приповиједања, П. Кочић, Св. Ћоровић, Б. Станковић, Руђер Бошковић, А. Г. Матош и Т. Ујевић. Преводио је пјеснике словеначке модерне. Уочено је да му је Б. Станковић претеча у обради еротских тема; да му је Св. Ћоровић близак по увођењу источњачких тема и мотива повезаних са домаћим тлом; да му је Матавуљ близак по темпераменту и приповједачком мајсторству; да је причу „Проба” написао по угледу на Кочићеву „Суданију”. Пажљиво је читао и проучавао историјске записе, љетописе и друге списе Прокопија Чокорила, 
Стаке Скендерове и Јоаникија Памучине, па фра Грге Мартића и Ивана Франа Јукића, односно све што му је могло послужити као грађа и изазов.

\section{Поетика приповедања}

„(...) Јер, приповедач и његово дело не служи ничем ако на један или на други начин не служи човеку и човечности. (...)"

Иво Андрић, „О причи и причању”

Мисаони меланхолик, мудрац, Иво Андрић је нужно био есејиста, па је већ запажено да је есеј у темељима сваког његовог дјела, у самој сржи његове умјетности и његове поетике. Зато је говор о његовој поетици незамислив без увида у његову есејистику, при чему дужна пажња мора бити указана и Андрићевој бесједи изговореној у Стокхолму приликом уручивања Нобелове награде 10. децембра 1961. године, насловљеној једноставно и прецизно, андрићевски, према предмету који освјетљава: „О причи и причању”. У њој су згуснуте неке од најзначајнијих Андрићевих идеја о приповједачкој умјетности. А умјетност приповиједања - писање приповиједака и романа - задавала му је много муке; по томе је био веома близак Вуку Караџићу. Андрић је изнутра разумијевао Вукове муке с „намјештањем ријечи” у приповијеткама:

„На све сам се жалио, као што то чине и други, некад мање некад више него други, али на једно се никад пожалио нисам, на велику, сталну тешкоћу коју имам код писања приповедака. А то ми је била и остала највећа и најтежа ствар у животу."

О тој „највећој и најтежој ствари у животу” проговорио је Андрић у својој свечаној бесједи онако како је иначе као писац чинио - из саме ствари: 
„Код описа ствари, људи или догађаја, треба оперисати само суштинама. Преко облика и њихових мена, али само суштинама. Треба говорити из средишта ствари које се описују; не са површине, још мање са тачке гледишта читаоца, него из сржи онога што сте изабрали за предмет и што читалац треба да види, схвати и осети."

Свечани говор Ива Андрића у Стокхолму одређен је тренутком и природом жанра. Он је подразумијевао израз захвалности Нобеловом комитету Шведске академије, при чему би се нешто кратко рекло о својој малој земљи и њеној књижевности, док би највећи дио излагања био посвећен општим разматрањима у вези са награђеним приповједачким дјелом. И тај главни дио говора морао је бити ограничен просторно и временски - на неколико минута, односно на три-четири странице текста - што је било искушење и за једног мајстора сажимања какав је Андрић несумњиво био.

Наш нобеловац је своју бесједу компоновао прстенасто: израз захвалности се налази на њеном почетку и на самом крају. Своју домовину је представио као „малу земљу међу световима”, која убрзано и „по цену великих жртава и напора" настоји да у свим областима живота, па и у култури, „надокнади оно што јој је необично бурна и тешка прошлост ускратила". Тако је славни писац и искусни дипломата покушао да заинтересује странце за своју малу земљу, и то како за њене напоре убрзаног развитка тако и за њену необично бурну и тешку прошлост, о чему, између осталога, говори и његово награђено дјело - роман На Дрини ћуприја.

Оцјењујући да је награђивањем њега и његовога дјела бачен сноп свјетлости и на књижевност његове мале земље, чији писци све запаженије и успјешније настоје да се интегришу у свјетску књижевност, стари мајстор изговара своју захвалност и у име књижевности којој припада. 
У другом, знатно дужем дијелу бесједе, Андрић је проговорио „о причи и причању уопште”, избјегавши да суди о своме дјелу или да га тумачи. Он је и овом приликом истакао више пута поновљену мисао „да је говор уметничког дела чистији и јаснији ако се не меша са живим гласом његовог ствараоца"; да писац не треба да тумачи своје дјело, и при том се позива на искуства свјетских писаца: Монтескијеа, који је тврдио да „писци нису добре судије својих дела”, Гетеа, који је формулисао правило: „Уметниково је да ствара а не да говори!" и Албера Камија.

Твори, творче, не говори - то је начело кога се Иво Андрић држао цијелог свога живота, па је и у часу кад се од њега очекивало да проговори о своме дјелу, приликом уручивања највишег међународног признања, одолио искушењу самотумачења и личне приче, опредијеливши се за говор „о причи и причању уопште”. Да би се боље разумјела та дистанца према себи, ваља се опет присјетити Андрићевих фрагментарних „Бележака за писца”, овдје већ цитираних, толико сродних Знаковима поред пута.

У првом фрагменту поменутих „Бележака” Андрић говори о писцу видећи његову судбину у бављењу појединостима, „ситним послом са најужим могућим видиком”. Чим покуша да ради „на широко”, одвојивши се од појединачног и имајући у виду цјелину, „све се замути и оплића". А чим се врати појединачном призору, ријечима и реченици, осјећа како се и цјелина склапа. А онда поентира односом писца и завршеног дјела:

„А кад дело буде једном завршено, онда се оно и онако одвоји од пишчеве свести и добије за њега ново значење, посве другачије од онога које је имало док је рад трајао. Могло би се рећи да дело за писца умре оног дана кад га он заврши. После, остаје књига."

Тако је то и у Андрићевој прози. Такав је и однос Андрићевих неимара према мосту и ћуприји: дјело и 
стваралац се у једном часу неминовно одвајају, заувијек. Писац јесте највећа и најчуднија прича, али зато што говори из средишта ствари, а на крају се неминовно одваја од свога дјела:

„Највећа и најчуднија прича то је писац сам. (Он је ватра, а све што пише то су само искре. Ватра, али под условом да остане у стварима и да говори из њих не учествујући у њиховој површној и променљивој игри и не имајући свога дела ни у чему.)"

Само кад је „унутарњи глас ствари”, писац је на свом мјесту. Чим се покаже, чим истури себе у први план, он квари сву чаролију:

„Писац је, кад је на своме месту, унутарњи глас ствари и тумач свих међусобних односа његових; он им даје лик, има и право место у васиони коју сам ствара и коју ми, читаоци, вољно примамо."

Зато писац мора да чува своје лично ја као погубну опасност, а поготово своја чуђења и изливе личних осјећања када покушава да дочара неки лик или догађај:

„Писац не сме да се чуди ничему. Његова мисао иде упоредо са догађајима, развија се, расте, пада, застаје. Освртање уназад, извиривање унапред, везивање оног што је било са оним што ће бити, ишчуђавање и мудровање над догађајима и поводом њих, све су то несумњиви знаци рђавог писца, тј. писца који то није и који ради посао за који нема звања, дара ни смисла. Писац нема осећања, он је осећање. Оно што се зове осећајност смрт је уметности."

Ових неколико ставова баца додатну свјетлост на бесједу у Стокхолму. Из њих је јасније Андрићево схватање имперсоналности приповиједања, односно његова усмјереност на „причу и приповедање уопште”. А тај говор о „причи и приповедању уопште” Андрић започиње овом реченицом:

„На хиљаду разних језика, у најразноличнијим условима живота, из века у век, од древних патријар- 
халних причања у колибама, поред ватре, па све до дела модерних приповедача која излазе у овом тренутку из издавачких кућа у великим светским метрополама, испреда се прича о судбини човековој, коју без краја и прекида причају људи људима.”

Прича и причање показују се као чудо које се догађа кроз вјекове, без прекида и без краја, у свим временима, мјестима и на свим језицима свијета, у најразличитијим околностима. Прича и причање су вјечни, па из Андрићеве реченице излази да је причање и слушање прича вјечна људска потреба којој краја нема. Мијењају се начини и облици причања, а остаје потреба човјекова да прича и да слуша причу. Људи људима говоре о људима и свијету, о некаквој стварности. И све те разнолике и разноврсне приче, на свим језицима свијета, као да се сливају и згушњавају у „исту причу” - у причу о човјеку и његовој судбини.

Откуда она - та „иста прича” - и чему служи? Какве су јој природа и функција? Шта је она и зашто је људи - од дјетињства, још бесловесни, па до гашења свијести - радо слушају, причају или препричавају? Каква је то магија у њој и око ње? Велики писац нема категоричног одговора, већ нијансира своје дилеме. Његови одговори су у знаку ријечи можда или у знаку знака питања. Иво Андрић јесте модеран, али није помодан писац. Он има на уму комплетно људско искуство приповиједања: усмено као и писано; приповиједање у колиби, крај огњишта, око ватре, и читање најновије књиге у осами; Шехерезаду као и Камија; приповиједање о прошлости као и приповиједање о садашњости. Зато ће прво поменути Шехерезаду:

„А та прича као да жели, попут причања легендарне Шехерезаде, да завара крвника, да одложи неминовност трагичног удеса који нам прети, и продужи илузију живота и трајања. Или можда приповедач својим 
делом треба да помогне човеку да се нађе и снађе? Можда је његов позив да говори у име свих оних који нису умели или, оборени пре времена од живота-крвника, нису стигли да се изразе? Или то приповедач можда прича сам себи своју причу, као дете које пева у мраку да би заварало свој страх? Или је циљ тога причања да нам осветли, бар мало, тамне путеве на које нас живот често баца, и да нам о том животу, који живимо али који не видимо и не разумемо увек, каже нешто више него што ми, у својој слабости, можемо да сазнамо и схватимо; тако да често тек из речи доброг приповедача сазнајемо шта смо учинили а шта пропустили, или би требало чинити, а шта не. Можда је у тим причањима, усменим и писменим, и садржана права историја човечанства, и можда би се из њих могао бар наслутити, ако не сазнати, смисао те историје. И то без обзира на то да ли обрађују прошлост или садашњост."

Андрић је, прилике су, сумњао у историографску слику прошлости, „историје”; више је вјеровао бајкама, легендама, причама - „правој историји”. То је и сумња у високе домете рационалистичког сазнања историје; и повјерење у причу и причање.

Прошлост или садашњост? Ето питања којим су често досађивали Андрићу, а на које је он ријетко одговарао. Овдје је одговорио у име писаца „историјских приповедака и романа". Писац се увијек бави човјеком и људском судбином, крупним појавама и проблемима. И прошла прича, као и садашња, ако су добре, говоре о универзалном, најдубљем у човјеку; постављају права и посљедња питања. Пред писцем је увијек човјек и његова судбина. И овдје ћемо поменути сјећање пјесника Рајка Петрова Нога на један разговор између Ива Андрића и Меше Селимовића: „Прошлост је оно што остаје”, рекао је Андрић. То би могло да значи: прошлост у мојој прози је оно што држим да је вјечно, што није више прошлост већ свевременост, али што, због 
своје увјерљивости, има временску и просторну конкретизацију. Оно што је универзални, златни талог приче о људској судбини. Вјечни талог вјечне приче:

„Кад је реч о приповедању које има за предмет прошлост, треба напоменути да има схватања према којима би писати о прошлости требало да значи пренебрегнути садашњицу и донекле окренути леђа животу. Мислим да се писци историјских приповедака и романа не би сложили са тим и да би пре били склони да признају да сами стварно и не знају како ни када се пребацују из оног што се зове садашњост у оно што сматрамо прошлошћу, да са лакоћом, као у сну, прелазе прагове столећа. Најпосле, зар се у прошлости као и у садашњости не суочавамо са сличним појавама и истим проблемима? Бити човек, рођен без свога знања и без своје воље, бачен у океан постојања. Морати пливати. Постојати. Носити идентитет. Издржати атмосферски притисак свега око себе, све сударе, непредвидљиве и непредвиђене поступке своје и туђе, који понајчешће нису по мери наших снага. А поврх свега, треба још издржати и своју мисао о свему томе."

Писац, дакле, с обје стране произвољне црте између прошлости и садашњости, има посла са истом човјековом судбином; с питањем: како разумјети човјека и како испричати лијепу причу. А Андрићев идеал „живог ткања приче" крајње је једноставан - досегнути идеал љепоте кроз једноставност и увјерљивост; приповиједати што љепше, што значи - што једноставније и убједљивије:

„Тако, и с оне стране црте која произвољно дели прошлост од садашњости писац сусреће ту исту човекову судбину коју он мора уочити и што боље разумети, поистоветити се са ғом, и својим дахом и својом крвљу је грејати, док не постане живо ткање приче коју он жели да саопшти читаоцима, и то што тепше, што једноставније, и што убедљьивије." (подвукао Ј. Д.) 
Једино што је важно и пресудно, што остаје или пропада - јесте дјело само; по њему се писац памти или заборавља. Без дјела нема писца. Иво Андрић је поштовалац дјела и његове аутономије.

Будући да се занимао за прошлост и историју, да су његови романи типолошки означавани као „историјски”, Андрић се у два кратка пасуса осврће на писце историјских романа и на њихова дјела. Није историјски роман велики по томе што ће дати беспрекорну историјску слику прошлости, већ по томе колико је у њему даха вјечности. И древна времена казују о човјеку колико и садашње, а почесто и много више, јер је писац у прилици да заузме дистанцу према јунацима и догађајима; да их обликује без погубног притиска дневних догађаја, личности и моћи:

„Писац историјских романа могао би на своје дело да стави као натпис и као једино објашњење свега, и то свима и једном заувек, древне речи: 'Cogitavi dies antiquos et annos aeteornos in mente habui'. (Размишљао сам о древним данима и сећао се година вечности.)

Па и без икаквог натписа, његово дело као такво говори то исто.“

Није, дакле, најважније да ли писац дочарава прошлост или садашњост, „или се смело залеће у будућност“: „оно што је при том главно, то је дух којим је надахнута његова прича, она основна порука коју људима казује његово дело.“ А ту прописа ни правила нема нити их може бити. Човјек прича и пише своју причу према „својој унутарњој потреби и мери својих наслеђених или стечених склоности и схватања и снази својих изражајних могућности.“

Стваралачка слобода се подразумијева; то Андрић решава у пола реченице: „И сваког треба пустити да слободно прича“. Знао је наш писац колико је слобода стваралаштва драгоцјена, а колико је кроз историју 
угрожавана. Знао је да је она први услов размаха приче и причања. Можда је из таквог знања радије понирао у прошлост; тиме је умањивао могућност неспоразума са савременицима. А можда је то била превасходно ствар склоности и темперамента: Иво Андрић је, доиста, волио историју и био историчар у најплеменитијем значењу те ријечи.

Слобода подразумијева човјекову одговорност. Када је о причи и причању ријеч, то је морална одговорност онога који пише и прича. Али то не значи да писац не треба да пише о овој или оној теми или сфери живота, већ да његова прича не буде „затрована мржњом ни заглушена грмљавином убилачког оружја, него што је могућно више покретана љубављу и вођена ширином и ведрином слободног људског духа“. Пишући о нашој књижевности послије Првог свјетског рата, Андрић је у њене прве врлине и заслуге убрајао њену чистоту и слободу од мржње, упркос жртвама и неправдама које су ту мржњу могле изазвати. Он се, доиста, мржње клонио, али га то није спасило да и послије смрти, да и дан данас буде предмет мржње, па чак и забране, изгона његових страница и дјела из школске лектире и из програма. Та мржња и те забране ући ће у историју бешчашћа и лудила краја 20. и почетка 21. вијека.

Иво Андрић је своју стокхолмску бесједу поентирао љубављу, ширином и ведрином слободног људског духа и службом човјеку и човјечности. Али не примитивном, слугеранском, плитком политикантском службом - јер то је издаја умјетности - већ оном која поштује слободу и ведрину духа, чува дух приповиједања и испреда вјечну причу човјека човјеку о човјеку.

„Јер, приповедач и његово дело не служе ничем ако на један или на други начин не служе човеку и човечности."

Литература која ништа не говори о човјеку, људској патњи и људским напорима да се одупре злу и ужасима 
овога свијета, нема прави разлог свога постојања. Она губи свој смисао ако човјек човјеку не говори о човјеку.

Андрић је ту вјечну причу говорио за живота. И данас је говори. Сматрамо часним живјети и радити у славу те приче; сматрамо се привилегованим што ту причу тумачимо кад већ не умијемо да је причамо. Јер, и прича о причи јесте прича о човјеку.

\section{Рецепција}

Значајна рецепција његових дјела на другим језицима почиње 1937. године, када му излази на пољском избор приповједака; сличан избор ће се појавити 1939. на њемачком, у преводу А. Шмауса, и на бугарском. Рат ће прекинути рецепцију, па ће се $\mathrm{Ha}$ Дрини ћуприја појавити 1948. у Софији; исте године излази у љубљани Травничка хроника. Први превод његовог романа на Западу биће њемачко издање На Дрини ћуприје (Цирих, 1953). Поводом објављивања Травничке хронике на француском држи предавање на Институту за словенске језике у Паризу (1956) о историјској грађи овог романа. У Паризу, Москви и Варшави излазе преводи На Дрини ћуприје, у Софији Проклете авлије, а у Будимпешти Травничке хронике. У Лондону му излази Травничка хроника (1958), а у Лајпцигу Госпођица. Током 1962. и доцније дјела му доживљавају изузетно снажну рецепцију у свијету, на шта је пресудно утицала Нобелова награда (1961). Тиме је скренута пажња свјетске јавности на југословенске књижевности и отворен пут југословенским писцима у свијет. Иронијом судбине, веће интересовање за његово дјело поновило се у доба растурања Југославије и грађанског рата у Босни и Херцеговини. О рецепцији ових дјела у свијету израђени су академски радови: Рецепција кюижевног дела Иве Андрића у САД (1984) Б. Микашино- 
вића и Рецепција књижевног дела Иве Андрића у Франиуској до 1975. године (1996) С. Ђорђића. Знатан број наших компаратиста дао је каткад изузетне прилоге о дјелу Ива Андрића у компаративном контексту (3. Константиновић, И. Тартаља, Н. Стипчевић, Р. Константиновић, Р. Вучковић, Ј. Новаковић, Б. Живојиновић, Д. Стојановић, Д. Недељковић, В. Д. Михајловић, М. Павловић и други).

Дјело Ива Андрића рано су запазили и у своје студије уврстили страни научници: италијански слависта У. Урбани пише о њему у контексту најновијих токова југословенске књижевности (1927), слично је учинио и њемачки слависта Ј. Матл (1925). Амбициозније научне анализе јавиле су се прије у свијету него код нас. $Ф$. Шерер посматра књижевност Балкана као „рудник балканског начина живота", као документарну грађу за своја етнографска истраживања (Балканско у новијој српско-хрватској литератури представљено у епском делу И. Андрића, Б- Станковића и А. Крстића, њем, 1950). Докторска дисертација Розе Мајер Иво Андрић садржина и облик неговог пјесничког дјела (њем, 1951), одбрањена у Грацу, први је покушај озбиљне књижевнонаучне анализе дјела Ива Андрића у иностранству; знатно је надилази модерно писана дисертација Регине Минде (Иво Андрић - студија о юеговој приповедачкој уметности, њем, 1962), рађена под руководством А. Шмауса, а на теоријским позицијама В. Кајзера, Р. Велека и О. Ворена, док је знатно испод овога нивоа М. С. Марковића Хиладу и једна ноћ Андрићева (1962). Енглески слависта Е. Д. Гој инсистира на унутрашњој еволуцији дјела, супротстављајући се регионалистичкој редукцији (Дело Ива Андрића, енг, 1963). Изузетно разумијевање опуса и културно-историјског контекста показао је пољски слависта Ј. Вјежбицки, знатно коригујући књигу Р. 
Минде (Иво Андрић, пољ, 1965). У Пољској су се дјелом Ива Андрића бавили К. Зурански и Б. Зјелински; у Италији П. Лазаревић ди Ђакомо, у Њемачкој Р. Лауер и Р Ходел, у Енглеској С. Хоксворт и Д. Норис, у Русији О. Кирилова, у Украјини П. Рудјаков и други.

Прву фазу у критичкој рецепцији дјела Ива Андрића чине критички записи до Првог свјетског рата, који су се јавили у хрватској критици (Љ. Визнер, В. Луначек и др). Другу фазу би чинио период до 1920, када се критика освртала на Ex Ponto и Немире. Већином су се огласили Андрићеви другови и књижевни сапутници. Ширу оцјену, у којој се наговјештава будући тумач дјела Ива Андрића, дао је М. Богдановић. Трајнију вриједност имају оцјене Н. Бартуловића, М. Црњанског и М. Богдановића. Трећа фаза је од 1920. до 1941. године, када дјело живи без пишчеве потпоре због његовог рада у дипломатији. Критика је истицала да је писац открио „најзанимљивији дио Босне”. Н. Мирковић је објавио прву обимнију студију о Андрићу, прво у СКГ, па као засебну књигу (1938). Четврта фаза обухвата период од 1945. до 1954. На три романа и приповијетке има мало одзива: пригушена књижевном политиком критика се тешко обнављала. Пета фаза (1954-1961) везује се за Проклету авлију, Одабране приповетке и Лица. Запажени су рад Ђ. Радовића и појава младих критичара (Б. Михајловић, П. Палавестра, Р. Тошовић). П. Џаџић оцјењује Проклету авлију као „најзначајнији подвиг послератне прозе”; С. Куленовић у њој види срж Андрићевог стваралаштва. Прва посљератна српска књига о Андрићу потиче од П. Џаџића (1957), који ће о њему написати још три књиге. Роман је и у средишту пажње И. Тартаље и В. Филиповића. О лирско-есејистичким иновацијама у приповијеткама касније су писали В. Ђурић и Д. Живковић. Нобе- 
лова награда усмјерава све рефлекторе на Андрића. У зборнику Иво Андрић (1961) И. Тартаља објављује рад „Есеји и записи Ива Андрића”, из којега ће се развити изузетна књига о Андрићевој поетици Приповедачева естетика (1979), а затим слиједи збирка огледа Пут поред знакова $(1991,2006)$. Јављају се обимнији, синтетични радови: Д. Живковића о стилу; В. Глигорић неутралише раније оцјене. Објављене су докторске тезе: М. Шамића (Историјски основи Травничке хронике, 1962), М. И. Бандића (1963), Бранка Милановића (Андрићева есејистика и юегово књижевно дјело, монографија: Андрић, Загреб, 1966) и Ж. Станојчића (Језик и стил Ива Андрића, 1967). О Андрићевом статусу у српској, хрватској и југословенској критици ради докторску тезу Р. Вучковић (Наша критика и Андрићево кюижевно дело, 1965). Н. Милошевић је контрастно изучавао Крлежу и Андрића; потом се појављују студије Р. Вучковића, Д. Пувачића, Ј. Новаковић, Ж. Ђукић Перишић и др. Издање Сабраних дела, посебно постхумно први пут објављених књига, означило је нову фазу у рецепцији Ива Андрића, која широм свијета добија велике размјере. Андрић се такође проучава у контексту авангарде, „модернистичког приповедања” (М. Пантић) или се анализирају његова појединачна дјела. Посебан значај имају зборници радова о дјелу Ива Андрића и Свеске Андрићеве задужбине (излазе од 1982, најмање једном годишње). Према Андрићевој тестаментарној вољи, сваке године, од 1975. (добитник Д. Михаиловић) додјељује се Андрићева награда за приповијетку или збирку прича на српском језику.

Андрићева дјела била су изазов за филм и позориште: Аникина времена у режији В. Погачића (1954), Жеђ (1969, ТВ Загреб, у адаптацији К. Новосела и у режији J. Марушића); Петар Зец је према Андрићевим 
дјелима радио сценарија за ТВ драме и ТВ филмове: Злоставтане, Знакови, Разговор с Гојом и Суседи. Поред ТВ драме у режији Миленка Маричића (1984) Проклета авлија је више пута успјешно драматизована. Игране су представе Аникина времена, Проклета авлија, Крилати мостови, Лица, На Дрини ћуприја, Знакови поред пута, Омер-паша Латас, Аска и вук, Злостављағье, а као монодраме Злоставтағье, Знакови, Ћоркан, Бечлијка Омер-паше Латаса (1992), Мостови (2001).

\section{Почасни докторати}

Иво Андрић је био почасни доктор Универзитета у Сарајеву 1962; почасни доктор Јагелонског универзитета у Кракову 1964; почасни доктор Универзитета у Београду 1972.

\section{Награде}

Између низа награда које је Иво Андрић добио издвајамо сљедеће: Награда Српске краљевске академије из фонда Љубе Михаиловића за књигу Приповетке, 1925; Награда из фонда Коларчеве задужбине за књигу Приповетке, 1931; Награда за књижевност Владе ФНРЈ за књигу Нове приповетке, 1949; Награда Савеза књижевника Југославије за Проклету авлију, 1955; Повеља за животно дело Савеза књижевника Југославије, 1956; Нобелова награда за књижевност, 1961; Награда АВНОJ-а, 1967; Награда „Давид Штрбац", 1967; Двадесетседмојулска награда БиХ, 1970; Специјална Вукова награда Културно-просветне заједнице Србије, 1971. 


\section{Одликовања}

Орден Официра обновљене Пољске, 1926; Орден Црвеног крста, 1936; Орден Великог командира обновљене Пољске, 1937; Орден Великог официра Легије части, 1937; Орден Светога Саве I реда, 1938; Орден заслуга за народ I реда, 1952; Орден Републике са златним венцем, 1962; Орден јунака социјалистичког рада, 1972.

Јован Делић

\section{Литература}

Огледи и студије / Велибор Глигорић. - Београд : Просвета, 1959 (Београд : Београдски графички завод). - 330 стр. : ауторова слика ; 19 cm. - (Бразде : библиотека савремених југословенских писаца. коло 4 ; књ. 20)

Problemi, pisci i dela. 2 / Radovan Vučković. - Sarajevo : "Veselin Masleša", 1976 (Sarajevo : Oslobođenje). - 363 str. ; 20 cm. - (Savremena domaća književnost / ["Veselin Masleša", Sarajevo])

Сабрана дела Иве Андрића/ [приредили Вера Стојић ... и др.]. - Београд : Просвета ; Загреб : Младост ; Сарајево : Свјетлост ; Љубљана : Државна заложба Словеније ; Скопје : Мисла ; Титоград : Побједа, 1981.

Свеске Задужбине Иве Андрића. - Београд : Задужбина Иве Андрића, 1982 -

Ivo Andrić (1892-1975) : lični fond : katalog / Olga Mučalica, Anđelija Dragojlović. - 1. izd. - Beograd : Zadužbina Ive Andrića, 1988 (Beograd : Srboštampa). - 628 str. : faks.; $24 \mathrm{~cm}$

Огледи о Иви Андрићу / Славко Леовац. - Београд : Српска књижевна задруга, 1993 (Београд : Култура). - 198 стр. ; 18 cm. - (Мала библиотека Српске књижевне задруге) 